NBER WORKING PAPER SERIES

\title{
KNOWLEDGE MANAGEMENT, INNOVATION AND PRODUCTIVITY: A FIRM LEVEL EXPLORATION BASED ON FRENCH MANUFACTURING CIS3 DATA
}

\author{
Elizabeth Kremp \\ Jacques Mairesse \\ Working Paper 10237 \\ http://www.nber.org/papers/w10237
NATIONAL BUREAU OF ECONOMIC RESEARCH
1050 Massachusetts Avenue
Cambridge, MA 02138
January 2004

We are grateful to Dominique Foray and Fred Gault for encouraging us strongly to perform this study, and we thank SESSI ("Service des Etudes et Statistiques Industrielles") for giving us access to the French CIS3 data. We have also benefited from comments by Rachel Griffith, Bronwyn Hall, Kathryn Shaw and other participants to workshops at the NBER (Summer Institute 2002), IFS (November 2002) and ZEW (March 2003). The views expressed herein are those of the authors and not necessarily those of the National Bureau of Economic Research.

C2004 by Elizabeth Kremp and Jacques Mairesse. All rights reserved. Short sections of text, not to exceed two paragraphs, may be quoted without explicit permission provided that full credit, including (C) notice, is given to the source. 
Knowledge Management, Innovation and Productivity:

A Firm Level Exploration Based on French Manufacturing CIS3 Data

Elizabeth Kremp and Jacques Mairesse

NBER Working Paper No. 10237

January 2004

JEL No. C35, L60, O31, O32

\begin{abstract}
In modern knowledge driven economies, firms are increasingly aware that individual and collective knowledge is a major factor of economic performance. The larger the firms and the stronger their connection with technology intensive industries, the more are they likely to set up knowledge management $(\mathrm{KM})$ policies, such as promoting a culture of information and knowledge sharing $(\mathrm{C})$, motivating employees and executives to remain with the firm $(\mathrm{R})$, forging alliances and partnerships for knowledge acquisition (A), implementing written knowledge management rules (W). The French 1998-2000 Community Innovation Survey (CIS3) has surveyed the use of these four knowledge management policies for a representative sample of manufacturing firms. The micro econometric analysis of the survey tends to confirm that knowledge management indeed contributes significantly to firm innovative performance and to its productivity. The impacts of adoption of the four surveyed KM practices on firm innovative and productivity performance are not completely accounted by firm size, industry, research \& development $(\mathrm{R} \& \mathrm{D})$ efforts or other factors, but persist to a sizeable extent after controlling for all these factors.
\end{abstract}

Elizabeth Kremp

Secretariat d'Etat a L'Industrie

Service des Statistiques Industrielles

Chef de departement des etudes structurelles

20 Avenue de Segur

75353 Paris 07 SP

FRANCE

and NBER

elisabeth.kremp@industrie.gouv.fr
Jacques Mairesse

INSEE, CREST

15, Boulevard Gabriel PERI

92245 MALAKOFF CEDEX

FRANCE

and NBER

mairesse@ensae.fr 


\section{INTRODUCTION}

In the knowledge driven economy, firms are becoming more and more aware of the fact that knowledge is a resource requiring explicit and specific management policies and practices to be acquired, processed and exploited efficiently. ${ }^{2}$ Among other objectives, the role of knowledge management $(\mathrm{KM})$ policies and practices is to foster all types of firm innovation, whether process or product oriented or mainly organizational, and to improve firm productivity and its medium and long term competitive advantage. ${ }^{3}$

As part of the pilot project initiated by OECD and Statistics Canada to study firm KM behavior, SESSI, the statistical Agency of the French ministry of manufacturing industries, has introduced a set of four new questions, specifically relating to important and relatively well-defined KM policies, in the French Third Community Innovation Survey (CIS3). ${ }^{4}$ They respectively concern the existence in the firm of a written policy (W) of knowledge management, of a culture (C) of knowledge sharing, of a policy of retention (R) of employees and executives, and of alliances (A) and partnerships for knowledge acquisition (see Box 1 in the Appendix).

${ }^{2}$ For presentation of the knowledge economy in general and in the French context in particular, see Foray, 2003, and Commissariat général du Plan, 2002.

${ }^{3}$ In what follows we will use the words KM policies and practices (or even methods or strategies) interchangeably.

${ }^{4}$ For a summary presentation of the overall results of CIS3 for French Manufacturing, see Lhomme, 2002. 
In the first section of our exploratory study, we document the diffusion of these four KM policies among French manufacturing firms in 2000, and that of three other related practices (also surveyed in CIS3). In the second section we provide evidence on the complementarity of KM policies, in the sense that firms tend to adopt them jointly, and we introduce an indicator of intensity of knowledge management (KMI). In the next two sections we make an attempt to assess the impacts of implementing KM policies on firm performance, controlling for a number of other factors, and investigate their complementarity also in the sense that their impacts are cumulative. In the fourth section we consider four indicators of firm innovative performance, the propensity and intensity in innovating and in patenting on products, while in the fifth we look similarly at firm productivity. We briefly conclude in the last section.

\section{I- DIFFUSION OF KNOWLEDGE MANAGEMENT}

\section{An increasing concern...}

Several reasons explain the increasing concern of firms for knowledge management. Firms have to deal with a more complex world because of rapidly changing technologies. Information and communication technologies (ICT) are ubiquitous, creating new needs and requiring appropriate organizational structures, facilitating the automation of some tasks and the outsourcing of others, supporting technological watch and improving access to 
external knowledge. Firms have to react faster to keep their competitive edge and to be able to build on all or part of their past experience. They are more and more aware of the fact that their competencies largely rely on individuals and on tacit knowledge special to the company. They are worried about the loss of skills caused by the mobility of their personnel and are striving to motivate their employees and executives to remain within the company, improving their career and remuneration prospects, setting up training courses and encouraging professionalism. Firms are also aware that they cannot maintain and develop their knowledge by relying only on internal forces. They have to form alliances and partnerships with other firms, competitors as well as suppliers and clients, to acquire new knowledge and expertise.

\section{...leading to the adoption of knowledge management practices, ...}

Over the past years, firms have adopted different knowledge management practices. In 2000, in manufacturing industries, nearly one out of two have implemented at least one of the four KM policies identified in the French CIS3 questionnaire (see Chart 1). More precisely, $28 \%$ of manufacturing firms with 20 employees or more declared that they have a culture to promote knowledge sharing (C), and almost as many (27\%) that they set up an incentive policy to keep employees and executives in the firm (R). Likewise, $23 \%$ of them

forged alliances or partnerships for knowledge acquisition (A), and significantly less (17\%) put into practice a written knowledge management policy (W). 


\section{...especially in large firms...}

The diffusion of $\mathrm{KM}$ policies is much more widespread in large than in small firms (see Chart 1). Setting up a special organization is much less critical, and more costly, in smaller firms where information circulates more easily and informal procedures can be efficient. In the larger firms, on the other hand, identifying the experts (the knowledge holders) within the company is essential vis-à-vis other employees and working with outside experts is an important asset. In 2000, almost four out of five $(80 \%)$ of the firms with 2,000 employees or more declared they had a knowledge sharing culture (C) or alliances for knowledge acquisition (A), while only one out of five (20\%) of those with 20 to 49 employees said so. Likewise, adopting a written knowledge management policy (W) is much more frequent in the large firms: one out of two $(50 \%)$ of the firms with 2,000 employees or more had one, and merely one out of ten (10\%) among the smaller firms.

\section{CHART 1 about HERE}

By contrast to large firms, small firms are likely to be more dependent on the expertise and know how of a few number of their employees, and much more concerned if they leave. That is possibly why the adoption of a policy to retain employees in the firm (R), even if much less common in the smaller firms than in the larger ones, is somewhat more frequent relative to the adoption of the three other policies. 


\section{...and in technology intensive industries.}

KM policies are also particularly widespread in the high and medium-high tech industries, such as the pharmaceutical industry, aeronautic and space construction or electronic component manufacturing (see Chart 2). In these industries, $40 \%$ to $45 \%$ of the firms have implemented policies to foster knowledge sharing (C), to retain employees (R), or to establish partnerships to acquire knowledge (A), and about $25 \%$ have adopted a knowledge written policy (W). The diffusion of KM policies is about half less prevalent in the low tech industries such as clothing and leather, publishing, printing and reproduction, or home equipment.

\section{CHART 2 about HERE}

\section{Knowledge management policies are more frequent in firms implementing new management methods...}

From 1998 to 2000, in the manufacturing industries, one firm out of five has implemented new methods of management in the broad sense, that is, with respect to other corporate functions, rather than just knowledge management. A good example is the development of project-based management practices that altered existing work relations within companies, and led to the progress of corporate cross-departmental culture. Unsurprisingly, knowledge management is more widespread in firms that have adopted 
such new management methods (see Table 1). Among these firms three out of four (76\%) have also implemented at least one of the four KM practices, while among firms that have not adopted new management methods, this is the case of less than two out of five $(37 \%)$.

\section{...in firms making $R \& D$ investments, innovating and patenting...}

Knowledge management is also prevalent among firms investing in research \& development (R\&D), innovating and patenting. In 2000, 30\% of French manufacturing firms with 20 employees or more have invested in R\&D, and 20\% have patents on products protecting part of their output, while from 1998 to 2000 about $35 \%$ have generated innovations on products or processes. The diffusion among these firms of all four KM practices is at least double than for the non innovating or non $R \& D$ doing firms and at least $60 \%$ higher than for the non patenting firms (see Table 1).

\section{TABLE 1 about HERE}

...and in innovating firms that use the Internet and ICT to acquire and share information.

As part of their strategy to foster innovation, firms make specific efforts to gain better information on technologies, products and materials, as well as about their customers, suppliers and competitors. They find such information from a wide range of sources: from universities and public or private research laboratories, in technical and economic 
databases, in professional journals and conferences, trade fairs and exhibitions. Indeed, $40 \%$ of innovating firms state that they use the Internet to acquire information for their innovating activities, $35 \%$ that they take advantage of ICT resources to share such information between employees, and $25 \%$ that they do both. Among this last group of firms, about $60 \%$ have a knowledge sharing culture (C) and $40 \%$ a written knowledge management policy (W), that is twice as many as for all manufacturing firms (see Table 1).

\section{II- COMPLEMENTARITY OF KNOWLEDGE MANAGEMENT PRACTICES}

\section{Firms tend to adopt knowledge management practices jointly, ...}

Looking at the occurrence of joint adoption of two among the four KM policies shows that firms view them as complementary and suggests that the basic reasons of their adoption are similar. Firms that implement one KM policy are much more likely to adopt a second one than firms which have not implemented the first one (see Chart 3 and Table A2 in the Appendix). For instance, three out of five firms, among the $28 \%$ which have a knowledge sharing culture (C), also implement an incentive policy to keep employees (R); one out of two also develop partnerships to acquire knowledge (A), and about one out of two have also a written knowledge management policy (W). On the other hand, among the $72 \%$ of firms declaring they did not have a culture of knowledge sharing, only one out of eight set up partnerships for knowledge acquisition (A) or implement an incentive policy 
for employees' retention(R), and fewer than one out of sixteen have a written knowledge policy (W).

\section{CHART 3 about HERE}

The complementarity of knowledge management practices is reflected in the high correlations, ranging from 0.30 to 0.50 , which we find between the binary indicators of adoption of the four KM policies (see Table A3 in the Appendix). It is also confirmed by the fact such correlations remain high when we try to control for various factors of adoption. The partial correlations between the four KM policies indicators, conditional on size and industry of the firms, and other control variables (i.e., the ones we also take into account in sections III and IV when investigating the impacts of KM practices on innovation and productivity) are still in the range of 0.15 to 0.40 (see Table A3 in the Appendix).

\section{...which suggests the definition of a knowledge management intensity indicator.}

The easiest way to take into account the complementarity of the different KM practices is to define a $\mathrm{KM}$ intensity indicator (KMI) as being simply the number of adopted practices. This indicator is thus equal to zero for a firm if the firm implements none of the four KM policies, and respectively to one, two, three or four, if it adopts at least one practice, two, three, or all four. It can be shown that KMI roughly corresponds to the first component in a principal factor analysis (or multiple correspondence analysis) of the correlation matrix (or the contingency table) of the four KM policies binary indicators. As 
expected from the pattern of adoption of each individual practice, KM intensity increases strongly with the size of the firm as well as with the industry technology intensiveness (see Chart 4). It is about 2.7 in firms with 2,000 employees or more as against 0.7 in firms with 20 to 49 employees. Likewise, it averages about 1.6 in high-tech industries and about 0.7 in low-tech intensity industries.

\section{CHART 4 about HERE}

\section{III- KNOWLEDGE MANAGEMENT AND INNOVATION}

Simple descriptive statistics show that the diffusion of KM practices is far from being complete among innovating firms or firms with patents, although much more advanced than among non innovating and non patenting firms (see Table 1). It thus makes sense to try to estimate the specific impact of adoption of $\mathrm{KM}$ practices on firm innovative performance, controlling for other (observed) factors and firm characteristics.

To assess firm innovative performance, we can use four variables from CIS3. The first two are the "propensity to innovate" and the (product) "innovation intensity", that is the binary indicator of whether the firm "has introduced during the period 1998-2000 any new or significantly improved products", and if yes "the share of turnover from these new or significantly improved products in the overall turnover of the firm in 2000". The other two variables, defined in an analogous way, are the "propensity to patent" and the "patent 
intensity", that is the binary indicator of whether the firm "has any valid product patent at the end of 2000" and if yes "the share of turnover protected by patents in the overall turnover of the firm in 2000". The average propensities to innovate and to patent are respectively about $35 \%$ and $20 \%$, while the average innovation intensity is about $15 \%$ for the innovating firms and the average patent intensity about $30 \%$ for the firms with patents (see Table A4 in the Appendix).

The fact that the innovation and patent intensity variables can only be known for the innovating and patenting firms is a very likely source of selectivity, which would result in biased estimates if we were to estimate the intensity relations separately from the propensity relations. Thus instead of simply considering independent (or seemingly unrelated) regressions to estimate the impact of knowledge management on the innovative performance variables, we consider jointly the propensity and intensity relations within the framework of a generalized tobit model. The tobit model allows to correct for selectivity biases in the intensity relation (or outcome equation) by specifying explicitly its linkage with the propensity relation (or selection equation), both through the correlation of the unobserved error terms in the two equations and through the sets of explanatory variables in these equations (i.e., the $\mathrm{KM}$ variables and the control variables). ${ }^{5}$

${ }^{5}$ In tobit models the selection equation is also specified as a probit (or normit) equation, which is more appropriate for a binary dependent variable, and the outcome equation as a linear regression, and it is assumed that the errors in these two equations are normally distributed (with correlation rho). Since the observed innovation and patent intensity variables are share variables, we use in fact as the dependent variable in the outcome equation their logit transformation [i.e., $\mathrm{z}=\log (\mathrm{y} /(1-\mathrm{y}))]$, so that the distribution of the "logit-shares" be (approximately) consistent with the assumed normal distribution (and limited to the 0 to 1 interval). We estimate the tobit model by the method of maximum 
As control variables in the propensity and intensity equations of our tobit model specification, we use all the available variables in CIS3 which we thought relevant: the firm size (i.e., by means of seven binary indicators, or six in addition to the constant) and industry (i.e., by means of fourteen binary indicators, or thirteen in addition to the constant), $R \& D$ intensity for $R \& D$ doing firms, and three other binary indicators for belonging to a group, for using new management methods, and for not doing R\&D. We can also introduce in the innovation and patent intensity equations another binary indicator to control for the acquisition and sharing of information using the Internet and other ICT tools. ${ }^{6}$ The mean and standard deviations, and more precise definitions of the control variables, are given in Table A4 in the Appendix.

In view of the strong complementarity of KM practices, we consider in fact four different specifications of the tobit model. In the first and simplest specification, or model 1, we use our $\mathrm{KM}$ intensity variable (KMI) as the only $\mathrm{KM}$ explanatory variable in the propensity and intensity equations, thus assuming that the individual impacts of the four KM practices are both (roughly) equal and linearly cumulative in the two equations. In the next two specifications, or models 2 and 3, we introduce, instead of KMI, four binary indicators in the propensity and intensity equations. In model 2, these indicators respectively correspond to the use of only one, or two, or three, or all four KM practices

likehood, making sure that we reach the absolute maximum(using TSP international version4.5). For an introduction to tobit models, see for example Greene "Econometric Analysis" (chapter 22, in the 1993 second edition). 
(i.e., $\mathrm{KMI}=1,2,3$ or 4 ), thus still implying that the impacts of the four practices are equal but allowing them to be more or less (non linearly) cumulative. In model 3 , they simply correspond to the separate use of each of the four $\mathrm{KM}$ practices (i.e., $\mathrm{KMC}=1, \mathrm{KMR}=1$, $\mathrm{KMA}=1, \mathrm{KMW}=1$ ), thus allowing that the impacts of the four practices be different and more or less cumulative. In the last and most general specification, model 4, we introduce, in addition to the four KM practices indicators, all their possible interactions, that is eleven other binary indicators (i.e., six " 2 by 2 " interactions such as $\mathrm{KMC} * \mathrm{KMR}=1$, four "3 by 3" interactions such as $\mathrm{KMC} * \mathrm{KMR} * \mathrm{KMA}=1$, and the "4 by 4" interaction $\mathrm{KMC}^{*} \mathrm{KMR} * \mathrm{KMA}^{*} \mathrm{KMW}=1$ which is identical to $\left.\mathrm{KMI}=4\right)$. Clearly model 1 is nested in the other three models, while models 2 and 3 are also nested in model 4, thus permitting us to test whether these models provide statistically different pictures: that is whether the four KM policies appear interchangeable and more or less cumulative, in terms of their impacts on firm innovative performance.

TABLES 2 and 3 and CHART 5 about HERE

The estimated impacts of the KM indicators (given directly in terms of the marginal effects on the propensity and on the intensity computed at the sample means, respectively as a probability in $\%$ and as a share in $\%$ ) are reported in Table 2 for our three first models, and also represented graphically in Chart 5. For model 1 these impacts are all statistically

\footnotetext{
${ }^{6}$ These questions on the Internet and ICT are asked in the French CIS3 only to the innovating firms.
} 
very significant; for models 2 and 3 most of them are also very significant in the innovation propensity and intensity equations, while only a few are in the patent propensity and intensity equations. ${ }^{7}$ Table 2 also reports the (maximum) log-likelihood values for the first three models, as well as for model 4 , from which we can simply compute the log-likelihood tests of model 1 against models 2, 3 and 4, and of models 2 and 3 against model 4 . These tests are reported in Table 3 . They show very clearly that the more parsimonious model 1 , with the KM intensity variable, cannot be statistically rejected against the other three models, even with a very low critical level of significance. Model 1 can thus be viewed as the (statistically) preferred model. The marginal effects of all variables, not only KM intensity but the R\&D doing binary indicator, $R \& D$ intensity and the other control variables, are shown for this model in Table A5 in the Appendix.

Our main results concern the statistical and economic significance of the estimated impacts of KM intensity. Regardless of their size and industry, of their R\&D efforts, of whether they belong to a group and have implemented new management methods, firms do tend to innovate and patent more extensively, if they have adopted KM policies. All else equal, when KM intensity increases by one, the propensity to innovate increases by $4 \%$ at the sample mean, that is from an average probability of $47.1 \%$ to $51.1 \%$, and innovation intensity increases by $1.6 \%$ for the innovating firms, from an average share of $15.8 \%$ to

\footnotetext{
${ }^{7}$ We do not report the estimated impacts for model 4, since they are not significant, with very few exceptions, for the eleven indicators of KM interactions (and practically not different for the four non-interacted KM indicators from the estimated impacts in model 3). We thus do not find evidence of complementarity (or substitutability) between the four KM policies, in the specific sense that if a firm has already adopted one such policy the impact on its performance of adopting another one would be higher (or weaker).
} 
$17.4 \%$. Similarly the propensity to patent increases by $1.6 \%$, from an average probability of $32.4 \%$ to $34.0 \%$, and patenting intensity increases by $3.1 \%$ for the patenting firms, from an average share of $30.5 \%$ to $33.6 \%$.

These estimated impacts on firm performance of KM policies are quite substantial, and all the more since they seem cumulative. They are not so huge, however, that one would have to conclude that they are necessarily wrong ("ils sont trop beaux pour être vrais"), and that they must be largely overestimated and our model badly misspecified. It is true that all the usual reasons of econometric misspecification potentially apply: omitted control variables and unobserved firm characteristics; endogeneity of right hand variables (i.e., of the $\mathrm{KM}$ indicators themselves and of the $\mathrm{R} \& \mathrm{D}$ and other control variables). These problems may be particularly serious with cross-sectional data as ours. There is not much that we can do to address them very effectively (and convincingly) at this stage, short of being able to gather more and better data (and preferably as panel data over a long enough period, or at least for two cross-sections a few years apart). On the other hand, an extreme degree of disbelief is not warranted. Even if the adoption of knowledge management has become fashionable among firms and for a number of them mainly a shibboleth for good management, one will expect that in average firms will not go through the various costs of implementing KM policies unless they have some real impacts on their performance. Anyhow, whether one views our findings with excessive skepticism or one is willing to give them some causal meaning, even if they are likely to suffer from significant overestimation, in both cases they remain statistically informative. At the minimum, they reflect significant underlying positive correlations, conditional on a fair number of relevant 
factors. Such descriptive correlations could have been negative or statistically not significant, and they are not.

As concerns the orders of magnitude of the estimates we find for the control variables, they look fairly reasonable on the whole, which is comforting (see Table A5). R\&D doing firms innovate and patent much more than non R\&D doing firms, and they also tend to innovate and patent more, the higher their $R \& D$ intensity. The estimated impacts of $R \& D$ intensity, however, may seem to be on the low side, although statistically very significant. A doubling of the average of $R \& D$ expenditures to sales ratio, which is of $1.7 \%$ for the innovating firms and of $2 \%$ for the patenting firms, would increase innovation intensity by only $1.2 \%$ and patenting intensity by a higher, though still modest, $5.3 \%$. One potential reason for these low estimates could be that instead of a measure of R\&D expenditures flow we should use a more appropriate measure of R\&D capital stock. The estimated impacts of the implementation of new management methods are statistically very significant, as well as substantial, being in the range of the impacts found for the adoption of $\mathrm{KM}$ policies (i.e., corresponding roughly to a $\mathrm{KM}$ intensity of 2 or 3). Lastly, there is a clear indication that firms belonging to a group tend to patent more, and a weaker one that they innovate more, while we find not specific impact of the use of Internet and ICT to acquire and share information. As could be expected the impact of firm size and industry is statistically significant and large, particularly so as concerns the impact of size on patent propensity and intensity. ${ }^{8}$

${ }^{8}$ For example, the differential impacts between the high tech electric and electronic components industry and the low tech textile industry (in terms of the marginal effects in \% 


\section{IV- KNOWLEDGE MANAGEMENT AND PRODUCTIVITY}

Besides focusing on the innovative performances of the firm, it is of interest to investigate whether the adoption of knowledge management practices also appears to have a specific impact, both statistically and economically significant, on labor productivity. To do so, we use basically the same models than the ones just considered for product innovation and patents, although with two differences. The first difference is that we can simply rely on a linear regression specification instead of a generalized tobit. This regression can be viewed as a simple extended production function (in log form), which is of current use in econometric studies of R\&D productivity. ${ }^{9}$ The second difference is that we introduce (log) physical capital per employee as an additional control variable, since these studies generally confirm that this is the major variable accounting for productivity differences among firms. ${ }^{10}$

computed at sample means) are about $7.5 \%$ on both the innovation and patent propensities and about $5.5 \%$ on both the innovation and patent intensities, while the differential impacts between the lowest size group of firms of 20 to 49 employees and the largest size group of 2,000 and more employees are respectively about $10 \%$ and $30 \%$, on the innovation and patent propensities and about $5.5 \%$ and $25 \%$ on the corresponding intensities.

9 We have also experimented using innovation or patent intensity (and an indicator for being innovative or patenting) in the production function production, instead of $R \& D$ intensity (and an indicator for doing $R \& D$ ). The results are basically the same, with $R \& D$ performing marginally better. For a review of econometric problems encountered in firm level econometric studies on R\&D productivity, in particular that of large discrepancies between cross-sectional and time-series estimates on panel data, see the survey, still useful though now incomplete, by Mairesse and Sassenou, 1991.

${ }^{10}$ We had to merge CIS3 with the French Survey of Enterprises in 2000 ("Enquete Annuelle d'Entreprise 2000") in order to be able to measure physical capital by the gross 


\section{CHART 6 about here}

The results of estimation and tests for productivity are reported in the last column of Tables 2, 3 and A5 and in Chart 6. The tests of the four models, corresponding to the different ways of entering knowledge management in the productivity equation, tell us a somewhat different story than for innovation and patenting. Model 3, in which the four KM policy indicators are included separately, performs slightly better than the others: It is statistically different from model 1 using our simple measure of KM intensity, but it is not statistically different from the less parsimonious model 4 with fully interacted KM policy indicators (while model 2 differs statistically from model 4, not from model 1). It is clear that the four KM policies do not appear exchangeable anymore and remain only partly cumulative. All else being equal, labor productivity is higher, and very significantly so, by about $10 \%$ for firms implementing a policy to retain executives and employees $(\mathrm{R})$ than for firms which do not, and by about 5\% for firms promoting a culture of knowledge sharing (C) than for firms which do not. At the opposite, all else equal, labor productivity is not statistically different (or barely so) between firms declaring that they have or that they have

book value of fixed assets, and also to measure labor productivity in terms of value added per employee (rather than total turnover per employee). This is why the "labor productivity sample" (3419 firms) is smaller by a few firms than the "full sample" (3474 firms) of the previous sections. Note that using this sample we could have also included physical capital intensity as an additional control variable in the innovation and patenting equations of section III. When we do so, however, our results remain basically unchanged; if anything, the estimated impacts of KM intensity on patenting propensity and intensity are slightly less significant and lower. 
not a policy to establish alliances to acquire knowledge (A), and a knowledge written policy $(\mathrm{W})$.

The estimated elasticities of the physical capital intensity and of R\&D intensity, though somewhat on the low side, are consistent with what could be expected from previous productivity studies (see Table A5 in the Appendix). Contrary to what we find for innovation and patenting, the estimated impact of the implementation of new management methods on productivity is barely statistically significant and if anything negative.

\section{V- TO CONCLUDE}

In this exploratory study of the diffusion and impact on firm performance of four specific knowledge management (KM) policies for a large representative sample of French manufacturing firms, we have found not very surprising results and more surprising ones (at least to us), some of them satisfactory, but others puzzling.

Among the expected results, we substantiate the fact that the diffusion of the four KM policies is much more advanced in the larger firms and in the technology intensive industries, and the fact that these practices appear highly complementary, firms tending to adopt them jointly. Among the less obvious but satisfactory findings, we observe that the impacts of KM practices on firm performance are in general statistically and economically significant and more or less cumulative, even controlling for firm size, industry and other 
important factors such as $R \& D$ intensity and physical capital intensity. It is also satisfactory to find that these estimated impacts are on the high side, but still in the range of values that one is a priori ready to accept as not implausible.

Less desirable and somewhat puzzling is the observation that our four specific $\mathrm{KM}$ practices are not only cumulative, but also apparently interchangeable in the case of innovative performance. In this case the model with KM intensity, simply defined as the number, varying from zero to four, of KM practices implemented by firms, performs statistically as well as the one with the four individual KM indicators. An explanation may be found in the collinearity (or high correlation) of these indicators naturally reflecting the complementarity of KM practices, but also in the intrinsic crudeness and subjective nature of such binary survey reported indicators, which is a likely source of measurement errors (in the form of a misclassification across the yes and no answers). Also rather puzzling is the finding that the estimated impacts of implementing new management methods in the broad sense are about as large as the impacts of KM practices on firm innovative performance, while they are if anything negative on firm productivity, unlike the positive significant impacts of employees retention and knowledge sharing culture policies ( $\mathrm{R}$ and C). 
Further studies are of course needed to confirm, better understand and enrich these exploratory results. ${ }^{11}$ It is clear that our econometric evidence of a significant impact of knowledge management on firm performance does not necessarily mean causality, although such a causal link is not a priori unlikely. It is also clear that our estimates are basically cross-sectional estimates and as such susceptible to various heterogeneity biases. Although they are not economically unreasonable, the orders of magnitude of the estimated impacts we find seem indeed rather high; but, even if they were to be divided by two, or even by three, they still would remain appreciable.

${ }^{11}$ In a recent micro econometric study based on information from a specific survey on "Firm Competencies to Innovate" for French manufacturing, merged with the innovation data from CIS2 (concerning the period 1994-1996), Galia and Legros find results which overall seem in accordance with ours. 


\section{BOX 1}

\section{Knowledge Management in the Third Community Innovation Survey (CIS3) for French manufacturing}

The Third Community Innovation Survey, which covers the period 1998-2000, was conducted in France jointly by INSEE and the Statistical Departments of the three Ministries respectively in charge of the manufacturing industries, agriculture, and commercial, financial and research and engineering services. It is a mandatory survey. The SESSI (Service des Etudes et Statistiques Industrielles) was in charge of surveying some 5500 manufacturing firms with 20 employees or more. Firms have been chosen randomly, using the business register based on legal units and according to the following stratified sampling design:

- $\quad$ all firms over 500 employees

- $\quad 1 / 2$ for firms from 100 to 499 employees

- $\quad 1 / 4$ for firms from 50 to 99 employees

- $\quad 1 / 8$ for firms from 20 to 49 employees

The rate of response was of $86 \%$, corresponding to an overall coverage of $89 \%$ of the total turnover for the manufacturing sector in 2000. See below the paragraph on the weighting of the results presented in this study. 


\section{The four questions on Knowledge Management...}

Four questions directly referring to firm policies and strategies of knowledge management have been introduced in the French CIS3 for manufacturing industries. These questions have been chosen as particularly meaningful among the 23 questions on knowledge management considered in the pilot survey by Statistics Canada (L. Earl and F. Gault, 2003) They are the following:

- By the end of 2000, did your firm have a written knowledge management policy? (W)

- Did it have a culture to promote knowledge sharing? (C)

- Did it put into practice an incentive policy to retain employees and executives in firm? (R)

- Did it forge partnerships or alliances for knowledge acquisition? (A)

\section{...and three other related ones.}

The French CIS3 for manufacturing industries also includes three other questions which can be related to the KM policies. They concern the adoption of new management practices in general and the use of Internet and ICT to acquire and share information for innovation purposes. They are the following:

- From 1998 to 2000, did your company implement new managerial methods?

- Do you use the Internet to acquire information (from the different possible sources, whether internal or external, private or public) for your innovating activities? 
- Do employees use ICT resources (data updates, Intranet, and so on) to share information from external sources?

Note that, since the answers to these last two questions on Internet and ICT are strongly correlated, we pooled them as one binary indicator in our econometric analysis. Note also that these questions were only asked to the innovating firms (that is, in accordance to the definitions of the OECD Oslo Manual, firms which have introduced new or significantly improved products or production processes during the 1998-2000 period).

\section{Weighting of Results}

The descriptive statistics shown in Charts 1 to 4 and Table 1 in the text, and in Tables A1 and A2 in the Appendix, are weighted to be representative of the manufacturing sector (i.e., in order to take into account the differences by size and industry in the sampling and response rates). However, the descriptive statistics in Table A4 in the Appendix and the econometric estimates presented in Charts 5 and 6 and Tables 2 and 3 in the text, as well as in Tables A3 to A5 in the Appendix, are not weighted. We have simply introduced size and industry indicators in all the estimated econometric models. We have also checked that the weighted econometric estimates were not meaningfully different from the unweighted ones. 


\section{REFERENCES}

Commissariat général du Plan, 2002 : La France dans l'économie du savoir : pour une dynamique collective [France in the Knowledge-Based Economy, a Country on the Move], La Documentation française, Novembre.

Earl Louise and Fred Gault, 2003: "Knowledge Management: Size Matters", forthcoming in Foray and Gault, OECD.

Foray Dominique, 2003: The Economics of Knowledge, MIT Press, Cambridge, Massachusetts, forthcoming.

Gallia Fabrice and Diego Legros, 2003: " Knowledge Management and Human Ressource Practices in an Innovation Perspective: Evidence from France", Mimeo May, Ermes - Université Panthéon-Assas Paris II.

Greene William, 1994: Econometric Analysis, 2d edition, MacMillan Publishing Company.

Lhomme Yann, 2002: "Technological Innovation in Industry", The Newsletter of Industrial Statistics, SESSI, no. 168 - December.

Mairesse Jacques and Mohamed Sassenou, 1991: "R-D and Productivity: a Survey of Econometric Studies at the Firm Level", Science-Technology Industry Review, Paris, OECD, nº 8, 1991, p. 9-43. 


\section{Chart 1: Diffusion of Knowledge Management Practices by Firm Size}

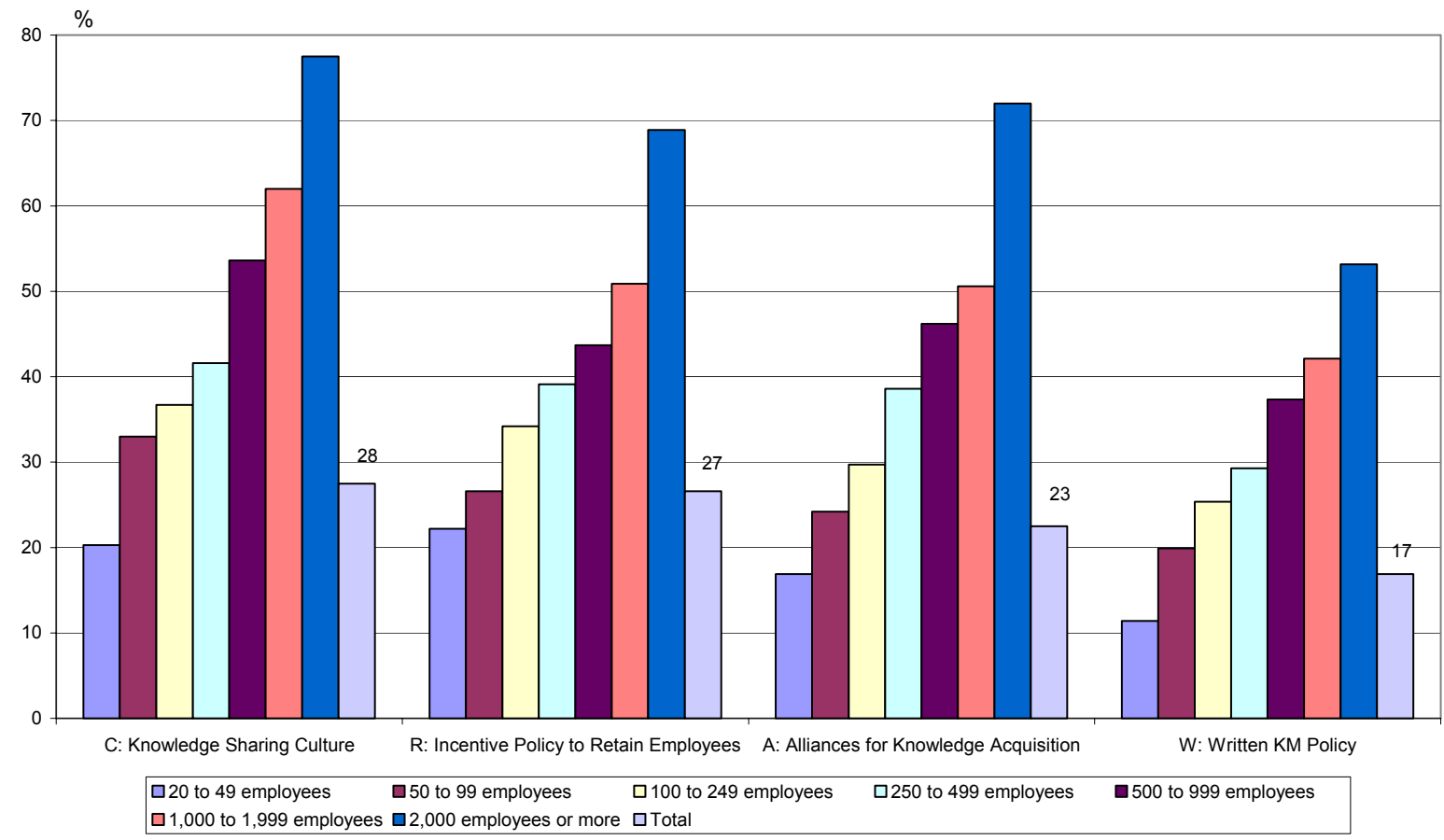

Scope: Manufacturing firms with 20 employees or more (excluding the food industry), weighted results.

Source: SESSI, CIS3 Survey. 


\section{Chart 2: Diffusion of Knowledge Management Practices by Technology Intensive Industries}

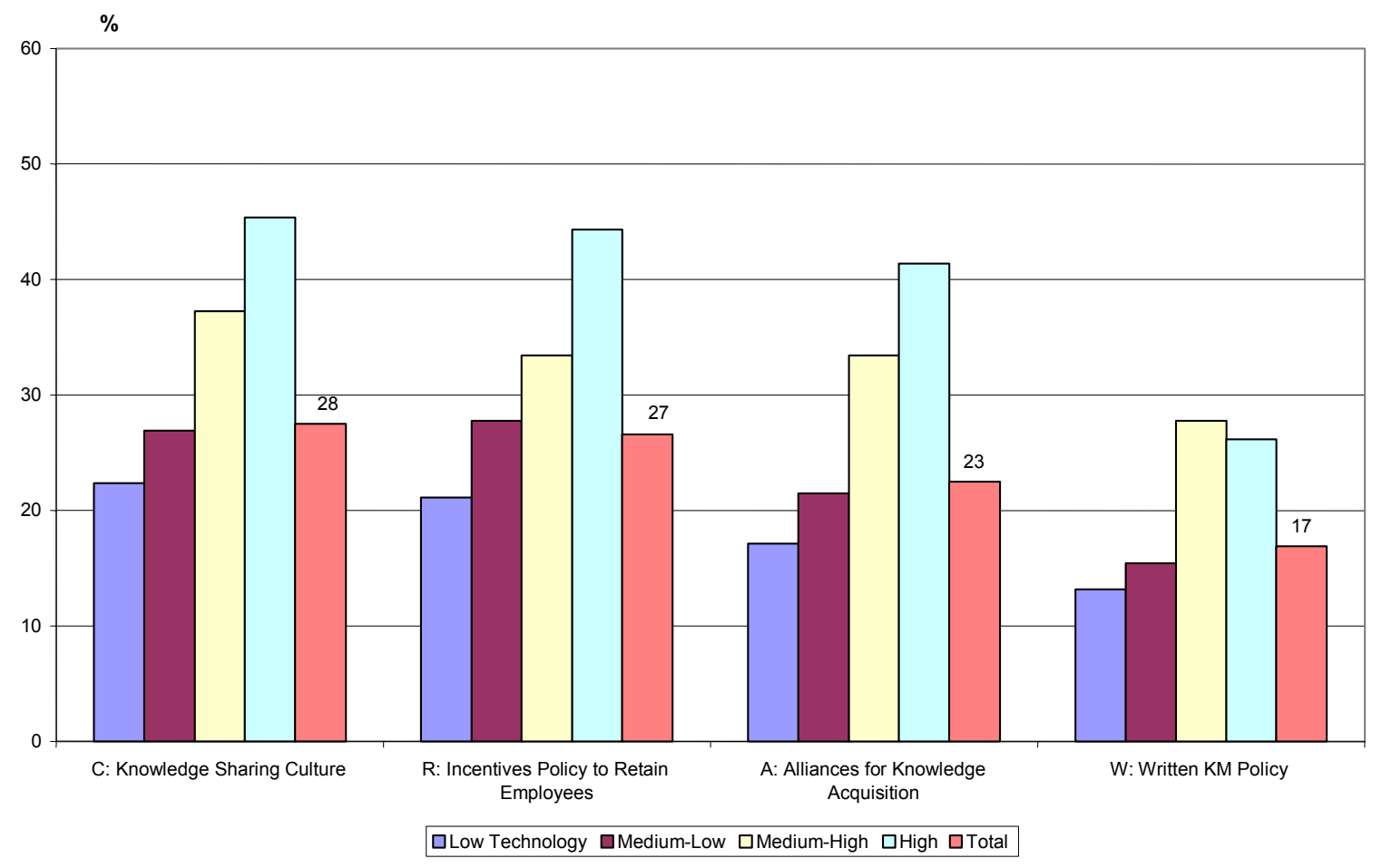

Definition: The classification of industries by technological intensity is mainly based on the average ratio of R\&D to output of the industry at the CITI rev2 level (OECD, 1997). See Table A1, in the Appendix.

Scope: Manufacturing firms with 20 employees or more (excluding the food industry), weighted results.

Source: SESSI, CIS3 Survey. 
Chart 3: Complementarity of Knowledge Management Practices

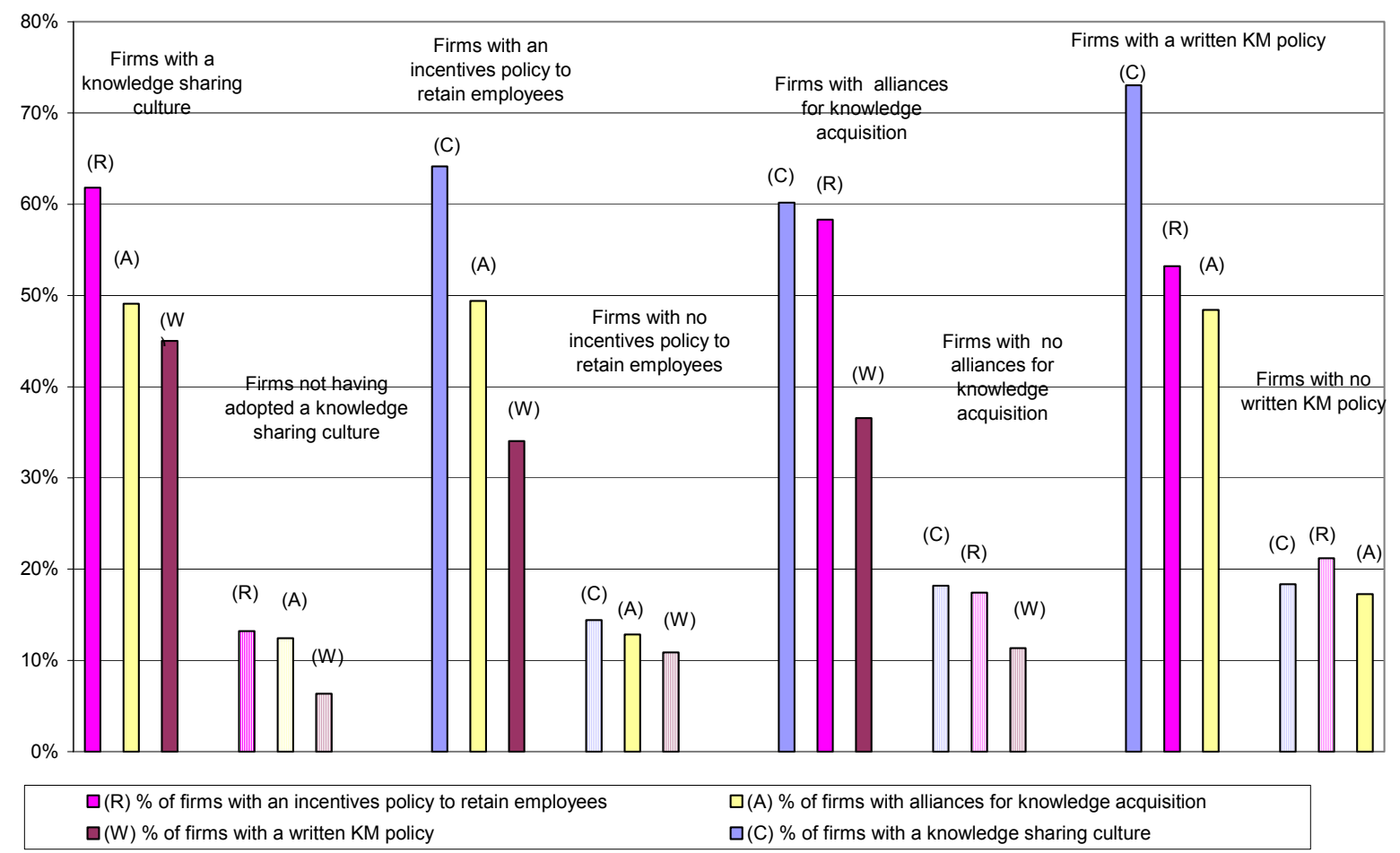

Among the $28 \%$ of firms having a culture of knowledge sharing, $62 \%$ have an incentive policy to retain employees, $49 \%$ have alliances for knowledge acquisition, and $45 \%$ a written policy of knowledge management.

Among the $72 \%$ of firms NOT having a culture of knowledge sharing, $13 \%$ have an incentive policy to retain employees, $12 \%$ have alliances for knowledge acquisition, and $6 \%$ have a written policy of knowledge management.

Scope: Manufacturing firms with 20 employees or more (excluding the food industry), weighted results.

Source: SESSI, CIS3 Survey. 


\section{Chart 4: Knowledge Management Intensity by Size and Technology Intensive Industries}



\section{Definitions}

The intensity of knowledge management is equal to zero when the firm implements none of the four KM practices; and to 1, 2, 3 or 4 respectively, when the firm implements at least one, two, three, or all four.

The classification of industry by technological intensity is mainly based on the average ratio of R\&D to output of the industry at the CITI rev2 level (OECD, 1997). See Table A1, in the Appendix for some indications about the link between classification of industries by technological intensity and the NES36 classification.

Lecture: Firms with more than 2,000 employees have a knowledge management intensity of 2.7; firms belonging to the high-intensive industries have a knowledge management intensity of 1.6.

Scope: Manufacturing firms with 20 employees or more (excluding the food industry), weighted results.

Source: SESSI, CIS3 Survey. 


\section{Chart 5: Estimated Impacts of Knowledge Management Practices on Innovation Performance, "all else equal"}

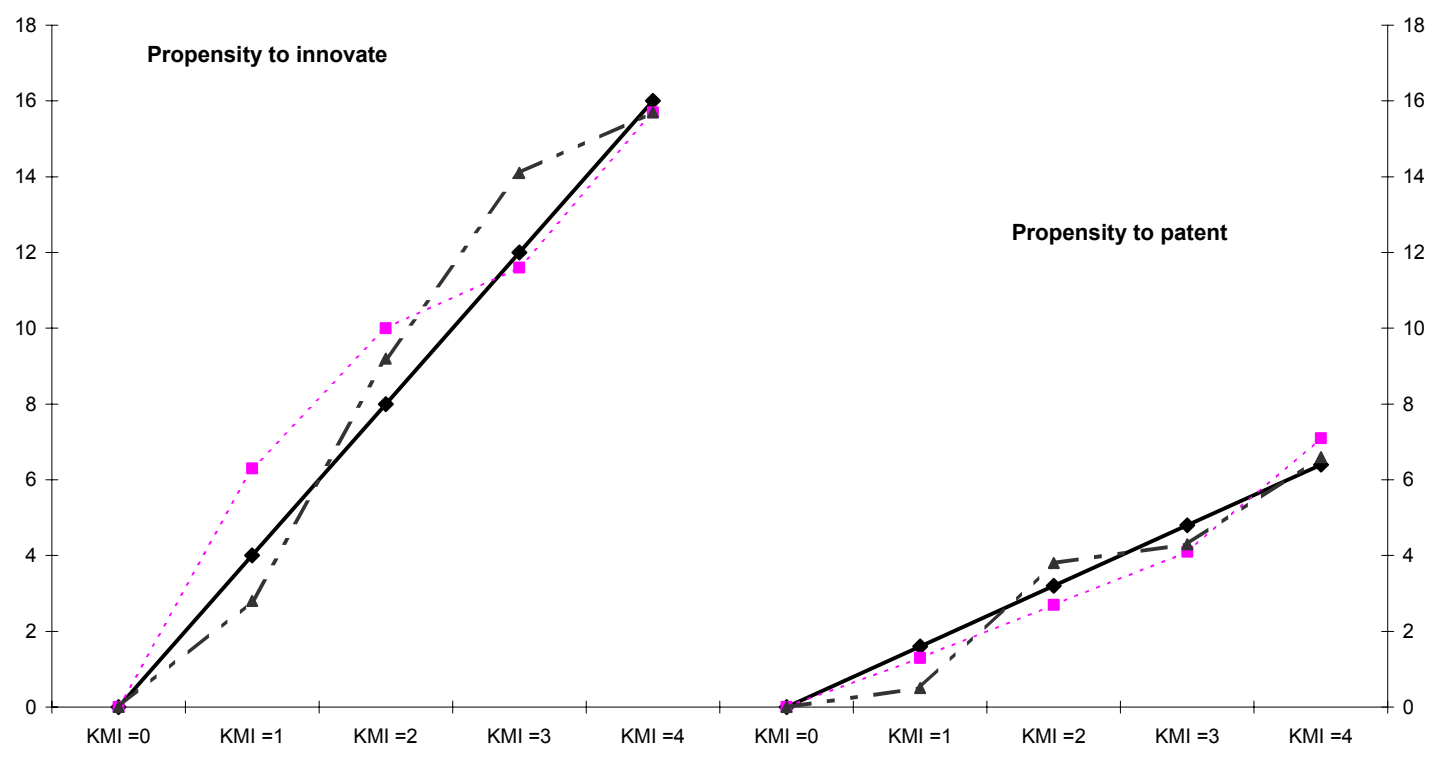

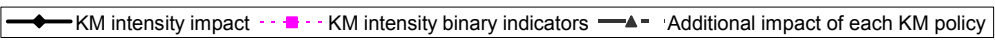




Chart 5 illustrates the estimated impacts of the adoption of the KM practices for the four innovation and patent propensity and intensity variables, where .

- the continuous straight line corresponds to the tobit model using the KM intensity variable, varying from 0 to 4 (Model 1, Table 3);

- the dotted line with squares corresponds to the tobit model using four KM intensity binary indicators, varying from 0 to 1 sequentially (Model 2, Table 3);

- the dotted line with triangles corresponds to the tobit model using the four KM indicators, varying from 0 to 1 in the following order: KM Culture (C), KM Retention policy (R), KM Alliance policy (A), KM Written policy (W) --where this order is in fact irrelevant (Model 3, Table 3).

Scope: Manufacturing firms with 20 employees or more (excluding the food industry), not weighted.

Source: SESSI, CIS3 Survey 


\section{Chart 6: Impacts of Knowledge Management Practices on Labor Productivity, "all other things being equal"}



The chart illustrates the estimated impacts of the adoption of the KM practices on labor productivity, where

- the continuous straight line corresponds to the regression using the KM intensity variable, varying from 0 to 4 (Model 1, Table 3);

- the dotted line with squares corresponds to the regression using four KM intensity binary indicators, varying from 0 to 1 sequentially (Model 2, Table 3);

- the dotted line with triangles corresponds to the regression using the four KM indicators, varying from 0 to 1 in the following order: KM Culture (C), KM Retention policy (R), KM Alliance policy (A), KM Written policy (W) --where this order is in fact irrelevant (Model 3, Table 3).

Scope: Manufacturing firms with 20 employees or more (excluding the food industry), not weighted.

Source: SESSI, CIS3 Survey 
Table 1: Diffusion of Knowledge Management Practices, according to the Adoption of New Management Methods, to R\&D and Innovating Activities, to Internet and ICT Use

\begin{tabular}{|c|c|c|c|c|c|c|c|}
\hline \multirow[t]{2}{*}{ Among } & \multirow{2}{*}{$\begin{array}{l}\% \text { of } \\
\text { firms }\end{array}$} & \multicolumn{5}{|c|}{$\%$ of firms having } & \multirow{2}{*}{$\begin{array}{c}\mathrm{KM} \\
\text { intensity }\end{array}$} \\
\hline & & $\begin{array}{c}\text { Knowledge } \\
\text { Sharing } \\
\text { Culture }\end{array}$ & $\begin{array}{c}\text { Incentive } \\
\text { Policy to } \\
\text { Retain } \\
\text { Employees }\end{array}$ & $\begin{array}{l}\text { Alliances } \\
\quad \text { for } \\
\text { Knowledge } \\
\text { Acquisition }\end{array}$ & $\begin{array}{c}\text { Written KM } \\
\text { Policy }\end{array}$ & $\begin{array}{l}\text { At least } \\
\text { one of the } \\
\text { four } \\
\text { policies }\end{array}$ & \\
\hline All Firms & & 28 & 27 & 23 & 17 & 45 & 0.9 \\
\hline R\&D Doing Firms & $30 \%$ & 45 & 42 & 39 & 28 & 71 & 1.6 \\
\hline NON R\&D Doing Firms & $70 \%$ & 20 & 20 & 15 & 12 & 34 & 0.7 \\
\hline Innovating Firms & $34 \%$ & 41 & 42 & 38 & 26 & 68 & 1.5 \\
\hline NON Innovating Firms & $66 \%$ & 19 & 19 & 14 & 12 & 34 & 0.7 \\
\hline Firms with patents & $20 \%$ & 40 & 39 & 35 & 26 & 62 & 1.4 \\
\hline Firms with NO patent & $80 \%$ & 25 & 24 & 20 & 15 & 41 & 0.8 \\
\hline $\begin{array}{l}\text { Firms having adopted } \\
\text { new management methods }\end{array}$ & $21 \%$ & 51 & 47 & 42 & 29 & 76 & 1.7 \\
\hline $\begin{array}{l}\text { Firms NOT having adopted } \\
\text { new management methods }\end{array}$ & $79 \%$ & 21 & 21 & 17 & 14 & 37 & 0.7 \\
\hline \multicolumn{8}{|l|}{ Innovating Firms which are: } \\
\hline $\begin{array}{l}\text {--Using the Internet and ICT for } \\
\text { acquiring and sharing information }\end{array}$ & $28 \%$ & 62 & 56 & 51 & 39 & 82 & 2.1 \\
\hline $\begin{array}{l}\text {--NOT using the Internet and ICT for } \\
\text { acquiring and sharing information }\end{array}$ & $68 \%$ & 37 & 36 & 34 & 21 & 63 & 1.3 \\
\hline
\end{tabular}

Among all firms, 28\% of them have implemented a knowledge sharing culture,..., 45\%

have adopted at least one $\mathrm{f}$ the four KM policies. Among all firms, 30\% of them do R\&D, $70 \%$ do not; etc. Among the R\&D doing firms, $45 \%$ of them have implemented a knowledge sharing culture; etc...

\section{Definitions}

The innovating firms are firms earning a turnover from new or significantly changed products on the market from 1998 to 2000 (in \%).

The firms with patents are firms having patented products in 2000 (in \%).

Scope: Manufacturing firms with 20 employees or more (excluding the food industry), weighted results. Source: SESSI, CIS3 Survey. 
Table 2: Estimated Impacts of Knowledge Management on Firm Innovation and Productivity, Controlling for Other Relevant Factors



The generalized tobit models for innovation (columns 1 and 2) and patents (columns 3 and 4) are estimated by the method of maximum likelihood. The linear regression model for labor productivity (column 5) is estimated by ordinary least squares (which coincides with maximum likelihood for the estimated coefficients and practically for their standard errors) $* * *, * *$, and * respectively indicate that the estimated coefficients are statistically 
significant at the $1 \%, 5 \%$ or $10 \%$ confidence level. These coefficients are directly given in the table in terms of the marginal effects computed at the sample means, respectively as a probability in $\%$ for the propensity to innovate and to patent equations, and as a share in $\%$ for the corresponding intensity equations. These estimated coefficients coincide with the (constant) marginal effects for the productivity equation. Rho is the estimated correlation coefficient between the error terms of the propensity and intensity equations of the generalized tobit models

All equations also include 14 industry indicators and 7 firm size indicators and the other relevant factors as defined in TableA4 in the Appendix. The coefficients (in terms of marginal effects) of all these other relevant factors are given in the Table A5 in the Appendix for the Model 1.

Scope: manufacturing companies with 20 employees or more (excluding the food industry), not weighted. Source: SESSI, CIS3 Survey. 
Table 3: Tests of the Regression Model with KM Intensity against Models with Four KM Intensity Binary Indicators, and the Four KM Practices Binary Indicators Alone or Fully "Interacted

\begin{tabular}{lccc}
\hline & $\begin{array}{c}\text { Innovation } \\
\text { propensity } \\
\text { and intensity }\end{array}$ & $\begin{array}{c}\text { Patent } \\
\text { propensity } \\
\text { and intensity }\end{array}$ & Productivity \\
\hline $\begin{array}{lccc}\text { Model 1 against model 2 } \\
\text { Chi2(n) }\end{array}$ & $\begin{array}{c}\text { 2.49 (6) } \\
\text { P-value in \% }\end{array}$ & $\begin{array}{c}0.79(6) \\
99 \%\end{array}$ & $\begin{array}{c}2.8(3) \\
43 \%\end{array}$ \\
Model 1 against model 3 & & & \\
Chi2(n) & $4.23(6)$ & $1.29(6)$ & $17.8(3)$ \\
P-value in \% & $65 \%$ & $97 \%$ & $0 \%$ \\
Model 1 against model 4 & & & \\
Chi2(n) & $18.33(28)$ & $9.1(28)$ & $26.6(14)$ \\
P-value in \% & $92 \%$ & $100 \%$ & $2 \%$ \\
Model 2 against model 4 & & & \\
Chi2(n) & $15.84(22)$ & $8.3(22)$ & $23.8(11)$ \\
P-value in \% & $82 \%$ & $100 \%$ & $1 \%$ \\
Model 3 against model 4 & & & \\
Chi2(n) & $14.1(22)$ & $7.8(22)$ & $8.8(11)$ \\
P-value in \% & $90 \%$ & $100 \%$ & $64 \%$ \\
\hline
\end{tabular}

Chi2(n) test statistics are directly computed on the base of the maximum log-likelihood values given for models 1, 2, 3 and 4 in Table 2.The number of degrees of freedom $n$ is the difference in the number of KM parameters between the encompassing model and the model tested.

Scope: Manufacturing companies with 20 employees or more (excluding the food industry), not weighted. Source: SESSI, CIS3 Survey. 


\section{Appendix}

\section{Table A1: Diffusion of Knowledge Management Practices by Industry in Manufacturing}

\begin{tabular}{|c|c|c|c|c|c|}
\hline \multirow[b]{2}{*}{$\begin{array}{l}\text { Industries by NES36 classification } \\
\text { (i.e., in } 14 \text { manufacturing industries) }\end{array}$} & \multicolumn{4}{|c|}{$\%$ of Firms per industry having } & \multirow[b]{2}{*}{$\begin{array}{l}\text { Knowledge } \\
\text { Management } \\
\text { Intensity }\end{array}$} \\
\hline & $\begin{array}{l}\text { Knowledge } \\
\text { Sharing } \\
\text { Culture }\end{array}$ & $\begin{array}{l}\text { Incentive } \\
\text { Policy to } \\
\text { Retain } \\
\text { Employees } \\
\end{array}$ & $\begin{array}{l}\text { Alliances } \\
\quad \text { for } \\
\text { Knowledge } \\
\text { Acquisition } \\
\end{array}$ & $\begin{array}{c}\text { Written } \\
\text { Knowledge } \\
\text { Manageme } \\
\text { nt Policy }\end{array}$ & \\
\hline Consumer Goods Industry & 21 & 23 & 19 & 11 & 0.73 \\
\hline Clothing and Leather Products $(L T)$ & 8 & 14 & 8 & 4 & 0.34 \\
\hline $\begin{array}{l}\text { Publishing, Printing and Reproduction } \\
(L T)\end{array}$ & 23 & 21 & 17 & 9 & 0.70 \\
\hline $\begin{array}{l}\text { Pharmaceuticals, Fragrances and } \\
\text { Cleaning Products }(M H \& H T)\end{array}$ & 40 & 39 & 37 & 28 & 1.46 \\
\hline Home equipment ( $L T, M L, M H \& H T)$ & 21 & 26 & 22 & 12 & 0.81 \\
\hline Automobile Industry ( $M L \& M H)$ & 33 & 32 & 20 & 24 & 1.08 \\
\hline Capital Goods Industry & 31 & 32 & 27 & 18 & 1.07 \\
\hline $\begin{array}{l}\text { Shipbuilding, Aircraft and Railroad } \\
\text { Construction (ML \& HT) }\end{array}$ & 46 & 28 & 34 & 28 & 1.37 \\
\hline $\begin{array}{l}\text { Mechanical Engineering Products (ML \& } \\
M H)\end{array}$ & 25 & 29 & 21 & 14 & 0.89 \\
\hline $\begin{array}{l}\text { Electric and Electronic Components ( } M H \\
\& H T)\end{array}$ & 44 & 40 & 40 & 27 & 1.50 \\
\hline Intermediate Goods Industry & 29 & 26 & 23 & 9 & 0.96 \\
\hline Mineral Products ( $L T \& M L)$ & 27 & 27 & 18 & 13 & 0.85 \\
\hline Textiles $(L T)$ & 25 & 19 & 19 & 12 & 0.75 \\
\hline Wood and Paper Industry $(L T)$ & 27 & 20 & 18 & 15 & 0.79 \\
\hline $\begin{array}{l}\text { Chemicals, Rubber \& Plastics (ML \& } \\
M H \text { ) }\end{array}$ & 36 & 31 & 30 & 27 & 1.23 \\
\hline $\begin{array}{l}\text { Metal Processing \& Metalworking }(L T \& \\
M L)\end{array}$ & 27 & 24 & 21 & 19 & 0.91 \\
\hline $\begin{array}{l}\text { Electric and Electronic Equipment (MH \& } \\
H T)\end{array}$ & 32 & 33 & 31 & 22 & 1.18 \\
\hline
\end{tabular}

\section{Definitions:}

This table is based on the NES36 classification, corresponding to 14 different manufacturing industries. The classification of industry by technological intensity is mainly based on the average ratio of R\&D to output of the industry at the CITI rev2 level (OECD, 1997). An approximate correspondence to the NES114 is possible but not to the NES36, the 
NES36 industries containing NES114 sub- industries of different technological intensity. To roughly indicate the degree of technological intensity of the 14 NES36 manufacturing industries, the existence of sub-industry of different technological intensity is noted in parentheses, where HT, MH, ML and LT stand respectively for High-Tech., Medium High tech., Medium Low tech. and Low Tech..

Scope: Manufacturing firms with 20 employees or more (excluding the food industry), weighted results. Source: SESSI, CIS3 Survey. 
Table A2: Complementarity of Knowledge Management Practices

\begin{tabular}{|c|c|c|c|c|}
\hline & \multicolumn{4}{|c|}{ in $\%$ of firms having } \\
\hline & $\begin{array}{l}\text { Knowledge } \\
\text { Sharing } \\
\text { Culture } \\
(28 \%)\end{array}$ & $\begin{array}{c}\text { Incentive Policy } \\
\text { to Retain } \\
\text { Employees } \\
(27 \%)\end{array}$ & $\begin{array}{l}\text { Alliances for } \\
\text { Knowledge } \\
\text { Acquisition } \\
(23 \%)\end{array}$ & $\begin{array}{c}\text { Written } \\
\text { Knowledge } \\
\text { Management } \\
\text { Policy } \\
(17 \%)\end{array}$ \\
\hline \multicolumn{5}{|l|}{$\%$ of Firms Having } \\
\hline Knowledge Sharing Culture & 100 & 64 & 60 & 73 \\
\hline Incentive Policy to Retain Employees & 62 & 100 & 58 & 53 \\
\hline Alliances for Knowledge Acquisition & 49 & 49 & 100 & 48 \\
\hline \multirow[t]{3}{*}{ Written Knowledge Management Policy } & 45 & 34 & 37 & 100 \\
\hline & \multicolumn{4}{|c|}{ In \% of Firms NOT having } \\
\hline & $\begin{array}{l}\text { Knowledge } \\
\text { Sharing } \\
\text { Culture } \\
(72 \%)\end{array}$ & $\begin{array}{c}\text { Incentive Policy } \\
\text { to Retain } \\
\text { Employees } \\
(73 \%)\end{array}$ & $\begin{array}{l}\text { Alliances for } \\
\text { Knowledge } \\
\text { Acquisition } \\
(77 \%)\end{array}$ & $\begin{array}{c}\text { Written } \\
\text { Knowledge } \\
\text { Management } \\
\text { Policy } \\
(83 \%)\end{array}$ \\
\hline \multicolumn{5}{|l|}{$\%$ of Firms Having } \\
\hline Knowledge Sharing Culture & 0 & 14 & 18 & 18 \\
\hline Incentive Policy to Retain Employees & 13 & 0 & 17 & 21 \\
\hline Alliances for Knowledge Acquisition & 12 & 13 & 0 & 17 \\
\hline Written Knowledge Management Policy & 6 & 11 & 11 & 0 \\
\hline
\end{tabular}

Among the $28 \%$ of firms having a culture of knowledge sharing, $62 \%$ have an incentive policy to retain employees, $49 \%$ have alliances for knowledge acquisition, and $45 \%$ a written policy of knowledge management. Among the $72 \%$ of firms NOT having a culture of knowledge sharing, $13 \%$ have an incentive policy to retain employees, $12 \%$ have alliances for knowledge acquisition, and $6 \%$ have a written policy of knowledge management.

Scope: Manufacturing firms with 20 employees or more (excluding the food industry), weighted results. Source: SESSI, CIS3 Survey. 
Table A3: Correlations between Knowledge Management Practices

\begin{tabular}{|c|c|c|c|c|c|}
\hline $\begin{array}{c}\text { Raw correlations } \\
\text { (before any controls) }\end{array}$ & $\begin{array}{l}\text { Knowledge } \\
\text { Sharing } \\
\text { Culture }\end{array}$ & $\begin{array}{l}\text { Incentive } \\
\text { Policy to } \\
\text { Retain } \\
\text { Employees }\end{array}$ & $\begin{array}{l}\text { Alliances } \\
\text { for } \\
\text { Knowledge } \\
\text { Acquisition }\end{array}$ & $\begin{array}{c}\text { Written } \\
\text { KM } \\
\text { Policy }\end{array}$ & $\begin{array}{c}\mathrm{KM} \\
\text { intensity }\end{array}$ \\
\hline Knowledge Sharing Culture & 1 & 0.47 & 0.40 & 0.48 & 0.81 \\
\hline Incentive Policy to Retain Employees & 0.47 & 1 & 0.40 & 0.28 & 0.74 \\
\hline Alliances for Knowledge Acquisition & 0.40 & 0.40 & 1 & 0.27 & 0.71 \\
\hline Written KM Policy & 0.48 & 0.28 & 0.27 & 1 & 0.68 \\
\hline KM intensity & 0.81 & 0.74 & 0.71 & 0.68 & 1 \\
\hline $\begin{array}{l}\text { Partial correlations } \\
\text { (after controlling for size, industry } \\
\text { and other relevant factors) }\end{array}$ & $\begin{array}{l}\text { Knowledge } \\
\text { Sharing } \\
\text { Culture }\end{array}$ & $\begin{array}{c}\text { Incentive } \\
\text { Policy to } \\
\text { Retain } \\
\text { Employees }\end{array}$ & $\begin{array}{l}\text { Alliances } \\
\text { for } \\
\text { Knowledge } \\
\text { Acquisition }\end{array}$ & $\begin{array}{l}\text { Written } \\
\text { KM } \\
\text { Policy }\end{array}$ & $\begin{array}{c}\mathrm{KM} \\
\text { intensity }\end{array}$ \\
\hline Knowledge Sharing Culture & 1 & 0.36 & 0.28 & 0.39 & 0.76 \\
\hline Incentive Policy to Retain Employees & 0.36 & 1 & 0.29 & 0.16 & 0.68 \\
\hline Alliances for Knowledge Acquisition & 0.28 & 0.29 & 1 & 0.16 & 0.64 \\
\hline Written KM Policy & 0.39 & 0.16 & 0.16 & 1 & 0.62 \\
\hline KM intensity & 0.76 & 0.68 & 0.64 & 0.62 & 1 \\
\hline
\end{tabular}

The (raw) correlation between the binary indicator of firm adoption of a culture of knowledge sharing $(C)$ and incentive policy to retain employees $(R)$ is of 0.47 , while the partial correlation is of 0.36 , after (linearly) controlling for size, industry and other factors (included as control factors in the propensity equation- see Table A5 in the Appendix).

Scope: Manufacturing firms with 20 employees or more (excluding the food industry), weighted results. Source: SESSI, CIS3 Survey. 
Table A4: Descriptive statistics

\begin{tabular}{|c|c|c|c|c|}
\hline & $\begin{array}{c}\text { Full sample } \\
\text { (3 } 474 \\
\text { firms) }\end{array}$ & $\begin{array}{c}\text { Innovating } \\
\text { firms sample } \\
\text { (1 } 635 \text { firms) }\end{array}$ & $\begin{array}{c}\text { Patenting } \\
\text { Firms sample } \\
\text { (1 } 125 \text { firms) }\end{array}$ & $\begin{array}{c}\text { Productivity } \\
\text { sample } \\
\text { (3 } 419 \\
\text { firms) }\end{array}$ \\
\hline \multicolumn{5}{|l|}{ Performance variables } \\
\hline Propensity to innovate & $\begin{array}{c}47.1 \\
(49.9)\end{array}$ & - & - & - \\
\hline Propensity to patent & $\begin{array}{c}32.4 \\
(46.8)\end{array}$ & - & - & - \\
\hline Innovation intensity & - & $\begin{array}{l}15.75 \\
(16.7)\end{array}$ & - & - \\
\hline Patent intensity & - & - & $\begin{array}{l}30.52 \\
(31.0)\end{array}$ & - \\
\hline $\begin{array}{l}\text { Labor productivity ( in } \mathrm{K} € \text { per } \\
\text { person) } \\
\text { Exolanatorv variables }\end{array}$ & - & - & - & $\begin{array}{l}50.56 \\
(0.47)\end{array}$ \\
\hline $\mathrm{KM}$ intensity & $\begin{array}{c}1.25 \\
(1.35)\end{array}$ & $\begin{array}{l}1.77 \\
(1.38)\end{array}$ & $\begin{array}{c}1.78 \\
(1.41)\end{array}$ & $\begin{array}{c}1.24 \\
(1.35)\end{array}$ \\
\hline Group Indicator & $\begin{array}{l}0.72 \\
(0.45)\end{array}$ & $\begin{array}{l}0.83 \\
(0.37)\end{array}$ & $\begin{array}{l}0.88 \\
(0.33)\end{array}$ & $\begin{array}{c}0.72 \\
(0.45)\end{array}$ \\
\hline $\begin{array}{l}\text { New management methods } \\
\text { Indicator }\end{array}$ & $\begin{array}{c}0.27 \\
(0.45)\end{array}$ & $\begin{array}{l}0.39 \\
(0.49)\end{array}$ & $\begin{array}{c}0.39 \\
(0.49)\end{array}$ & $\begin{array}{c}0.27 \\
(0.45)\end{array}$ \\
\hline $\begin{array}{l}\text { Internet and ICT for information } \\
\text { acquisition and sharing } \\
\text { Indicator }\end{array}$ & - & $\begin{array}{c}0.37 \\
(0.48)\end{array}$ & $\begin{array}{c}0.37 \\
(0.48)\end{array}$ & - \\
\hline Non R\&D doing Indicator & $\begin{array}{c}0.55 \\
(0.50)\end{array}$ & $\begin{array}{c}0.22 \\
(0.42)\end{array}$ & $\begin{array}{c}0.25 \\
(0.43)\end{array}$ & $\begin{array}{c}0.55 \\
(0.50)\end{array}$ \\
\hline $\begin{array}{l}\text { Physical Capital Intensity (in } \\
\text { K€ per person) }\end{array}$ & - & - & - & $\begin{array}{l}40.45 \\
(1.10)\end{array}$ \\
\hline Proportion of R\&D doing firms & $\begin{array}{c}0.45 \\
(0.50)\end{array}$ & $\begin{array}{c}078 \\
(0.42)\end{array}$ & $\begin{array}{c}0.75 \\
(0.43)\end{array}$ & $\begin{array}{c}045 \\
(0.50)\end{array}$ \\
\hline $\begin{array}{l}\text { R\&D intensity (in \%) } \\
\text { (for R\&D doing firms) }\end{array}$ & $\begin{array}{r}1.58 \\
(2.32)\end{array}$ & $\begin{array}{c}1.73 \\
(2.20)\end{array}$ & $\begin{array}{c}1.98 \\
(2.16)\end{array}$ & $\begin{array}{r}1.57 \\
(2.33)\end{array}$ \\
\hline
\end{tabular}

Standard errors in parenthesis. Labor productivity, physical capital intensity and R\&D intensity are introduced in $\log$ on the different models. In this table, for these three variables, we give the exponential of the mean of the log. The standard error corresponds to the log variable. 
Definitions: The propensity to innovate variable is measured by the proportion of firms earning a turnover from new or significantly changed products on the market from 1998 to 2000 (in \%).

The propensity to patent variable is measured by the proportion of firms having patented products in 2000 (in \%).

The innovation intensity variable is measured by the logit function of the share ( or "logitshare"), in the firm's total turnover in 2000 , of the turnover from new or significantly changed products introduced on the market from 1998 to 2000 (in \%).

The patent intensity variable is measured by the by the logit function of the share ( or "logit-share"), in the firm's total turnover in 2000, of the patented products sales (in \%).

The labor Productivity variable is measured by the logarithm of the firm's value added to the total number of employees in 2000 (in K€ per person).

The physical capital intensity variable is measured by the logarithm of the firm's gross book value to the total number employees in 2000 (in K€ per person).

The $R \& D$ intensity variable is measured by the logarithm of the share of the firm's R\&D expenditures in the firm's total turnover in 2000.

The knowledge management intensity variable is measured by the number (from 0 to four) of knowledge management practices implemented by firms (see definition in chart 3).

The group, new management methods, Internet and ICT for external data sharing use, and non $R \& D$ doing variables are binary $0-1$ indicators (respectively equal to 1 if the firms belong to a group, have adopted new management methods, Internet and ICT for external data sharing use, or are NOT doing R\&D).

The 14 industry and 7 size binary indicators are defined on the base of the classification of industries shown in Table A1 in the Appendix and of the groupings by total number of employees used in Chart 1 in the text.

Scope: Manufacturing companies with 20 employees or more (excluding the food industry), not weighted.

Source: SESSI, CIS3 Survey. 


\section{Table A5: Estimated Impacts of Knowledge Management Intensity, R\&D Intensity and Other Control Variables on Firm Innovation and Productivity}

\begin{tabular}{|c|c|c|c|c|c|}
\hline Impacts in \% & $\begin{array}{l}\text { Propensity } \\
\text { to innovate }\end{array}$ & $\begin{array}{l}\text { Innovation } \\
\text { Intensity }\end{array}$ & $\begin{array}{l}\text { Propensity } \\
\text { to patent }\end{array}$ & $\begin{array}{c}\text { Patent } \\
\text { intensity }\end{array}$ & $\begin{array}{c}\text { Labor } \\
\text { Productivity }\end{array}$ \\
\hline KM intensity & $\begin{array}{l}4.0^{\star \star *} \\
(0.5)\end{array}$ & $\begin{array}{l}1.6^{\star * *} \\
(0.4)\end{array}$ & $\begin{array}{l}1.6^{* * *} \\
(0.5)\end{array}$ & $\begin{array}{l}3.1^{* *} \\
(1.3)\end{array}$ & $\begin{array}{l}3.0^{* * *} \\
(0.6)\end{array}$ \\
\hline R\&D intensity & $\begin{array}{l}1.7^{* * *} \\
(0.6)\end{array}$ & $\begin{array}{l}1.2^{* * *} \\
(0.4)\end{array}$ & $\begin{array}{c}2.8^{* * *} \\
(0.6)\end{array}$ & $\begin{array}{l}5.3^{* * *} \\
(1.4)\end{array}$ & $\begin{array}{l}1.6^{* *} \\
(0.6)\end{array}$ \\
\hline Non R\&D doing Indicator & $\begin{array}{l}-43.4^{\star * \star} \\
(3.1)\end{array}$ & $\begin{array}{c}-19.8^{\star \star \star} \\
(2.3)\end{array}$ & $\begin{array}{c}-30.3^{\star * *} \\
(3.0)\end{array}$ & $\begin{array}{c}-48.3^{* * *} \\
(7.3)\end{array}$ & $\begin{array}{l}-13.9^{* * *} \\
(3.2)\end{array}$ \\
\hline Group Indicator & $\begin{array}{l}3.3^{* *} \\
(1.6)\end{array}$ & $\begin{array}{c}2.1 \\
(1.3)\end{array}$ & $\begin{array}{l}5.2^{\star \star *} \\
(1.8)\end{array}$ & $\begin{array}{c}13.0^{* *} \\
(5.0)\end{array}$ & $\begin{array}{c}3.8^{* * *} \\
(1.7)\end{array}$ \\
\hline $\begin{array}{l}\text { New management } \\
\text { methods Indicator }\end{array}$ & $\begin{array}{l}6.5^{* * *} \\
(1.5)\end{array}$ & $\begin{array}{c}3.9^{* \star *} \\
(1.0)\end{array}$ & $\begin{array}{l}2.6^{*} \\
(1.5)\end{array}$ & $\begin{array}{l}9.3^{* *} \\
(3.6)\end{array}$ & $\begin{array}{l}-3.2^{*} \\
(1.6)\end{array}$ \\
\hline $\begin{array}{l}\text { Internet and ICT for } \\
\text { information acquisition and } \\
\text { sharing Indicator }\end{array}$ & -- & $\begin{array}{c}1.5 \\
(0.9)\end{array}$ & -- & $\begin{array}{l}-0.8 \\
(2.9)\end{array}$ & -- \\
\hline Physical Capital Intensity & -- & -- & -- & -- & $\begin{array}{c}15.4^{* * *} \\
(0.7)\end{array}$ \\
\hline Log likelihood & \multicolumn{2}{|c|}{-4226.49} & \multicolumn{2}{|c|}{-4089.63} & -1650.55 \\
\hline $\begin{array}{l}\text { Root MSE } \\
\text { Rho }\end{array}$ & \multicolumn{2}{|c|}{0.73} & \multicolumn{2}{|c|}{0.94} & 39.36 \\
\hline $\begin{array}{l}\text { Number of firms } \\
\text { Mean of left hand variable }\end{array}$ & $\begin{array}{c}3474 \\
47.1\end{array}$ & $\begin{array}{c}1635 \\
15.8\end{array}$ & $\begin{array}{c}3474 \\
32.4\end{array}$ & $\begin{array}{l}1125 \\
30.5\end{array}$ & $\begin{array}{l}3419 \\
564.0\end{array}$ \\
\hline
\end{tabular}

This Table complements Table 2 in the case of Model 1 by giving the estimated impacts (in terms of marginal effects) of all the control variables (except the 6 size and 14 industry indicators). See the footnote to Table 2 for details and the footnote to Table A4 in the Appendix for the precise definitions of the variables.

Scope: Manufacturing firms with 20 employees or more (excluding the food industry), not weighted.

Source: SESSI, CIS3 Survey. 